\title{
FAKTOR-FAKTOR YANG BERHUBUNGAN DENGAN HASIL PEMERIKSAAN IVA TEST PADA WANITA PASANGAN USIA SUBUR
}

\author{
Nirmala Sari ${ }^{1}$ \\ Prodi D III Kebidanan Fakultas Vokasi Universitas Baiturrahmah ${ }^{l}$ \\ e-mail: nirmalasari@jurkeb.unbrah.ac.id ${ }^{l}$
}

\begin{abstract}
Cervical cancer is a primary malignant tumor originating from cervical squamous epithelial cells or the cervix. The cause of cancer that attacks the cervix in the female reproductive organs is infection with the HPV virus (human papillomavirus). Early detection of precancerous lesions in women of childbearing age couples can be done using the IVA test technique. Puskesmas Padang Pasir is one of the health centers that performs the IVA test with the highest examination achievement compared to other health centers in the city of Padang. In 2018, there were 271 positive IVA test results. The purpose of this study was to determine the risk factors of the results of the IVA test in women couples of childbearing age at the Puskesmas Padang Pasir, including the age at first sexual intercourse, the amount of maternal parity and the history of using hormonal contraceptives. This type of research used a case control design with 32 case respondents with positive IVA test results and 32 mothers with negative IVA test results. The data taken is the respondent's medical record data in 2020 from January to May. Data were analyzed univariately and bivariately using the chi-square statistical test. The results showed that there was a significant relationship between the age of the mother and the results of the IVA test $p=0.024$, the amount of parity with the results of the IVA test $p=0.003$ and the history of hormonal contraception with the results of the IVA test $p=0.000$. Based on the results of this study, it is hoped that health workers will further increase promotional and preventive efforts to prevent cervical precancerous lesions by educating cervical cancer risk factors, the importance of vaccination and administration of the HPV vaccine, and the importance of regular IVA tests.
\end{abstract}

Keywords: Cervical Cancer, IVA Test.

\begin{abstract}
ABSTRAK
Kanker serviks adalah tumor ganas primer yang berasal dari sel epitel skuamosa serviks atau leher rahim. Penyebab penyakit kanker yang menyerang leher rahim pada organ reproduksi wanita adalah infeksi virus HPV (human papillomavirus). Deteksi dini lesi prakanker pada wanita pasangan usia subur dapat dilakukan dengan menggunakan Teknik IVA test. Puskesmas Padang Pasir adalah salah satu puskesmas yang melakukan pemeriksaan IVA test dengan capaian pemeriksaan tertinggi dibadningkan puskesmas lainnya di Kota Padang. Pada tahun 2018 didapatkan hasil pemeriksaan IVA test positif sebanyak 271 orang. Tujuan dari penelitian ini adalah untuk mengetahui faktor-faktor risiko hasil penelitian pemeriksaan IVA test pada wanita pasangan usia subur di Puskesmas Padang Pasir diataranya faktor umur pertama kali ibu melakukan hubungan seksual, jumlah paritas ibu dan riwayat penggunaan kontrasepsi hormonal. Jenis penelitian ini menggunakan desain case control dengan jumlah responden kasus sebanyak 32 orang ibu dengan hasil IVA test positif dan 32 orang ibu dengan hasil IVA test negative. Data yang diambil adalah data rekam medis responden pada tahun 2020 dari bulan Januari sampai dengan bulan Mei. Data dianalisa secara univariat dan bivariat dengan menggunakan uji statistic chisquare. Hasil penelitian menunjukkan terdapat hubungan yang bermakna antara umur ibu dengan hasil IVA test $\mathrm{p}=0,024$, jumlah paritas dengan hasil IVA test $\mathrm{p}=0,003$ dan riwayat kontrasepsi hormonal dengan hasil IVA tes $\mathrm{p}=0,000$. Berdasarkan hasil penelitian ini diharapkan pihak tenaga kesehatan lebih meningkatkan upaya promotif dan preventif pencegahan lesi prakanker serviks dengan penyuluhan faktor risiko kanker serviks, pentingnya vaksinasi dan pemberian vaksin HPV, serta pentingnya pemeriksaan IVA tes secara berkala.
\end{abstract}

Kata Kunci : Kanker Serviks, IVA Test 


\section{Latar Belakang (Opsional)}

Kanker serviks adalah tumor ganas primer yang berasal dari sel epitel skuamosa serviks atau leher rahim. Penyebab penyakit kanker yang menyerang leher rahim pada organ reproduksi wanita adalah infeksi virus HPV (human papillomavirus). Kondisi ini umumnya disadari ketika telah memasuki stadium lanjut, kanker leher rahim merupakan kanker yang paling sering dijumpai dan merupakan penyebab kematian kedua setelah kanker payudara. ${ }^{(1)}$

WHO (world health organization) menyatakan bahwa penyakit kanker merupakan masalah kesehatan yang mengkhawatirkan karena menyebabkan kematian diberbagai negara di dunia termasuk di indonesia. Kanker serviks adalah kanker paling sering pada wanita dengan perkiraan 570.000 kasus baru pada tahun 2018 dan mewakili 6,6 \% dari semua kanker pada wanita. Sekitar $90 \%$ kematian akibat kanker serviks terjadi dinegara-negara berpenghasilan rendah dan menengah. Tingkat kematian yang tinggi dari kanker serviks secara global dapat dikurangi melalui pendekatan komprehensif yang mencakup pencegahan, diagnosis dini, skirining yang efektif dan program pengobatan. ${ }^{(2)}$

Setiap tahun, di dunia terdapat 500.000 kasus baru kanker serviks dan lebih dari 250.000 kematian. Di Indonesia yang berpenduduk sekitar 220 juta jiwa, terdapat sekitar 52 juta perempuan yang terancam kanker serviks. Penyebab utama dari kanker serviks adalah infeksi HPV (Human Papilloma Virus). Proses terjadinya karsinoma serviks sangat erat hubungannya dengan proses metaplasia. Perubahan biasanya terjadi pada daerah sambungan skuamous kolumnar (SSK) atau daerah transformasi. Prognosis kanker serviks dapat dibedakan berdasarkan kriteria morfometrik, penyebaran, serta usia. ${ }^{(3)}$

Penyebab utama dari kanker serviks adalah infeksi HPV (human papillomavirus) yang berada dalam tubuh manusia, HPV adalah sekelompok virus yang terdapat terdiri dari 150 jenis virus yg dapat menginfeksi sel-sel pada permukaan kulit, diketahui bahwa dna HPV dapat ditemukan pada 99\% kasus kanker serviks diseluruh dunia. ${ }^{(4)}$

Kejadian kanker serviks dipengaruhi oleh berbagai faktor, terdapat beberapa faktor resiko yang berpengaruh terhadap kanker serviks. yaitu faktor sosiodemografis yang meliputi pekerjaan, pendidikan, usia, status sosial ekonomi, dan faktor aktifitas sekual yang meliputi usia pertama kali melakukan hubungan seks, pasangan seks yang berganti-ganti, paritas, kurang menjaga kebersihan diri, merokok, menggunakan alat kontrasepsi orang dalam jangka lama yaitu lebih dari 4 tahun. ${ }^{(5)}$

Insiden kanker serviks sebenarnya dapat ditekan dengan melakukan upaya pencegahan primer seperti meningkatkan atau intensifikasi kegiatan penyuluhan kepada masyarakat untuk menjalankan pola hidup sehat, menghindari faktor risiko terkena kanker, melakukan imunisasi dengan vaksin HPV dan diikuti dengan deteksi dini kanker serviks tersebut melalui pemeriksaan pap smear atau IVA (inspeksi Visual dengan Asam Asetat). Saat ini cakupan "screening" deteksi dini kanker serviks di Indonesia melalui pap smear dan IVA test masih sangat rendah (sekitar 5\%) padahal cakupan "screening" yang efektif dalam menurunkan angkakesakitan dan angka kematian karena kanker serviks adalah $85 \%$. ${ }^{(6)}$

Upaya deteksi dini kanker serviks dengan cara melakukan pemeriksaan IVA Test, hal-hal yang perlu dikaji mengenai kesehatan reproduksi sebelum dilakukan pemeriksaan IVA Test, yaitu riwayat mestruasi pola pendarahan (misalnya pasca coitus atau mentruasi tak teratus), paritas atau jumlah kelahiran yang hidup, usia pertama kali berhubungan seksual, penggunaan alat kontrasepsi. Skrining dengan menggunakan metode IVA Test ini dipilih karena dapat dilakukan dengan cara sederhana, murah, nyaman, praktis dan mudah. Yaitu dengan hanya menggoreskan asam asetat (cuka) 3-5\% pada leher rahim lalu mengamati perubahanya dimana lesi prakanker dapat terdektesi apa bila terlihat bercak putih pada leher rahim. Pemeriksaan IVA Test memiliki akurasi yang sangat tinggi $(90 \%)$ dalam mendekteksi lesi atau luka prakanker. ${ }^{(7)}$

Dengan pemeriksaan yang murah yaitu biaya untuk pemeriksaan sudah dijamin dalam program jaminan kesehatan (JKN), pemeriksaan IVA Test prosedurnya tidak rumit tidak memerlukan persiapan dan tidak menyakitkan. Pemeriksaan IVA Test ini praktis yaitu dapat dilakukan dimana saja, tidak memerlukan sarana khusus, cukup tempat tidur yang sederhana dan representetif, specelum dan lampu, pemeriksaan ini dilakukan oleh bidan dan perawat yang terlatih

Puskesmas padang pasir merupakan puskesmas yang memiliki data IVA test positif tertinggi dikota padang. Pada tahun 2018 sebanyak 271 wanita dengan IVA test positif dan tahun 2019 terjadi penurunan dengan jumlah 51 wanita dengan IVA Test positif. Meskipun terjadi penurunan yang cukup banyak, akan tetapi pemeriksaan IVA test tetap dilakukan di puskesmas untuk deteksi dini lesi prakanker. Tujuan dari penelitian ini adalah untuk mengetahui faktorfaktor resiko hasil pemeriksaan IVA test pada wanita pasangan usia subur di Puskesmas Padang Pasir.

\section{METODE}

Penelitian ini merupakan penelitian analitik dengan desain case control. Penelitian ini telah dilaksanakan di Puskesmas Padang Pasir dengan melihat data rekam medis dari bulan Januari sampai Mei tahun 2020. Metode pengambilan sampel adalah 1:1 kasus dan kontrol, yaitu 32 orang responden kelompok kasusl dan 32 orang responden kelompok kontrol. Kelompok kasus adalah wanita pasangan usia subur dengan hasil IVA test positif, sedangkan 
kelompok kontrol adalah wanita pasangan usia subur dengan hasil iva test negative.

Pengumpulan data yang dikumpulkan adalah umur ibu pertama melakukan hubungan seksual, jumlah paritas, dan riwayat penggunaan kontrasepsi hormonal. Hasil pemeriksaan IVA test dilakukan oleh Bidan penanggungjawab pemeriksa IVA test dan data sudah didapatkan pada rekam medis pasien. Data dianalisis secara univariat dan bivariat menggunakan uji statistik chi square.

HASIL

Berdasarkan umur pertama kali melakukan hubungan seksual, ibu yang melakukan hubungan seksual dibawah umur $<20$ tahun lebih banyak ditemukan pada ibu iva test positif (65.6\%) dibandingkan ibu dengan iva tes negatif (34.4\%). Uji statistik Chi-Square menunjukkan terdapat hubungan yang bermakna antara hasil pemeriksaan IVA dengan umur wanita pertama kali melakukan hubungan seksual.

Berdasarkan jumlah paritas, ibu yang memiliki paritas > 3 lebih banyak ditemukan pada ibu iva tes positif $(77.3 \%)$ dibandingkan ibu dengan iva tes negative (22.7\%). Uji statistik Chi-Square menunjukkan terdapat hubungan yang bermakna antara hasil pemeriksaan IVA dengan jumlah paritas wanita.

Berdasarkan penggunaan kontrasepsi hormonal ibu yang menggunakan kontrasepsi hormonal 4-5 tahun lebih banyak ditemukan pada ibu iva tes positif (81.5\%) dibandingkan dengan ibu dengan iva tes negatif (18.5\%). Uji statistik Chi-Square menunjukkan terdapat hubungan yang bermakna antara hasil pemeriksaan IVA dengan penggunaan kontrasepsi hormonal wanita.

Tabel 1. Faktor Risiko Hasil Pemeriksaan IVA Pada Wanita Pasangan Usia Subur Di Wilayah Kerja Puskesmas Padang Pasir Tahun 2020

\begin{tabular}{|c|c|c|c|c|c|c|c|}
\hline \multirow[t]{2}{*}{$\begin{array}{l}\text { Faktor } \\
\text { Risiko }\end{array}$} & \multicolumn{2}{|c|}{$\begin{array}{l}\text { IVA Test } \\
\text { Positif }\end{array}$} & \multicolumn{2}{|c|}{$\begin{array}{l}\text { IVA Test } \\
\text { Negatif }\end{array}$} & \multicolumn{2}{|c|}{ Total } & \multirow[t]{2}{*}{$\begin{array}{c}\mathbf{p} \\
\text { value }\end{array}$} \\
\hline & f & $\%$ & f & $\%$ & n & $\%$ & \\
\hline \multicolumn{8}{|l|}{ Umur } \\
\hline \\
\hline \multicolumn{8}{|l|}{ berhubu } \\
\hline \multicolumn{8}{|l|}{$\begin{array}{l}\text { ngan } \\
\text { seksual }\end{array}$} \\
\hline $\begin{array}{l}\text { seksual } \\
<20 \text { thn }\end{array}$ & 21 & 65.6 & 11 & 34.4 & 39 & 100 & \multirow{3}{*}{0.024} \\
\hline$>20$ thn & 11 & 34.4 & 21 & 65.6 & 25 & 100 & \\
\hline Total & 32 & 50 & 32 & 50 & 64 & 100 & \\
\hline \multicolumn{8}{|l|}{ Jumlah } \\
\hline \multicolumn{8}{|l|}{ Paritas } \\
\hline$>3$ & 17 & 77.3 & 5 & 22.7 & 22 & 100 & \multirow[t]{3}{*}{0.003} \\
\hline$\leq 3$ & 15 & 35.7 & 27 & 64.3 & 42 & 100 & \\
\hline Total & 32 & 50 & 32 & 50 & 64 & 100 & \\
\hline \multirow{5}{*}{\multicolumn{8}{|c|}{$\begin{array}{l}\text { Riwayat } \\
\text { kontrase } \\
\text { psi } \\
\text { hormon } \\
\text { al }\end{array}$}} \\
\hline & & & & & & & \\
\hline & & & & & & & \\
\hline & & & & & & & \\
\hline & & & & & & & \\
\hline $4-5$ thn & 22 & 81.5 & 5 & 5 & 27 & 100 & \multirow[t]{2}{*}{0.000} \\
\hline$<4$ thn & 10 & 27.0 & 27 & 73.0 & 37 & 100 & \\
\hline
\end{tabular}

\begin{tabular}{lllllll}
\hline Total & 32 & 50 & 32 & 50 & 64 & 100
\end{tabular}

\section{PEMBAHASAN}

Berdasarkan umur pertama kali melakukan hubungan seksual, ibu yang melakukan hubungan seksual dibawah umur $<20$ tahun lebih banyak ditemukan pada ibu iva test positif (65.6\%) dibandingkan ibu dengan iva tes negatif (34.4\%). Uji statistik Chi-Square menunjukkan terdapat hubungan yang bermakna antara Hasil pemeriksaan IVA dengan umur wanita pertama kali melakukan hubungan seksual.

Hasil penelitian ini sama dengan penelitian yang dilakukan oleh Widiyanti, 2020 yang berjudul faktor-faktor yang mempengaruhi hasil pemeriksaan iva test di poliklinik Yayasan kanker Indonesia kota Cimahi yang menyatakan terdapat hubungan yang bermakna antara usia pertama ibu melakukan hubungan seksual dengan hasil iva test. Hasil penelitian Wahyuningsih 2014 yang berjudul faktor risiko terjadinya lesi prakanker serviks melalui deteksi dini dengan metode IVA menyatakan terdapat hubungan yang bermakna antara usia ibu pertama melakukan hubungan seksual dengan hasil iva test. ${ }^{(5,8)}$

Umur saat perkawinan $\leq 20$ tahun erat kaitannya dengan aktivitas seksual. Berbagai penelitian menunjukkan bahwa terdapat hubungan yang bermakna antara lesi prakanker dan kanker serviks dengan aktivitas seksual pada umur yang sangat muda, khususnya sebelum umur 20 tahun. Hal ini mungkin terkait dengan komplemen histon pada semen yang bertindak sebagai antigen. Kematangan sistem imun terutama mukosa serviks sendiri sangat rentan, kesempatan berganti partner sex yang terkait dengan risiko terkena infeksi juga tinggi. ${ }^{(9)}$

Berdasarkan hasil penelitian umur pertama kali melakukan hubungan seksual sangat mempengaruhi terjadinya iva tes positif. Responden yang melakukan hubungan seksual diumur < dari 20 tahun salah satu faktornya diakibatkan oleh faktor lingkungan dan pergaulan sekitar. Pihak puskesmas disarankan melakukan penyuluhan dan memberikan informasi tentang pernikahan dini dan dampaknya terhadap kesehatan.

Berdasarkan jumlah paritas, ibu yang memiliki paritas > 3 lebih banyak ditemukan pada ibu iva tes positif (77.3\%) dibandingkan ibu dengan iva tes negative (22.7\%). Uji statistik Chi-Square menunjukkan terdapat hubungan yang bermakna antara hasil pemeriksaan IVA dengan jumlah paritas wanita.

Widiyanti, 2020 yang berjudul faktor-faktor yang mempengaruhi hasil pemeriksaan iva test di poliklinik Yayasan kanker Indonesia kota Cimahi yang menyatakan terdapat hubungan yang bermakna antara jumlah paritas dengan hasil iva test. Hasil penelitian 
Wahyuningsih 2014 yang berjudul faktor risiko terjadinya lesi prakanker serviks melalui deteksi dini dengan metode IVA menyatakan terdapat hubungan yang bermakna antara jumlah paritas dengan hasil iva test. ${ }^{(5,8)}$

Wanita yang sering melahirkan akan berdampak pada perlukaan dan trauma pada organ reproduksi dan akhir dari dampak luka tersebut akan memudahkan infeksi HPV sebagai penyebab lesi prakanker serviks. Selanjutnya adanya perubahan hormonal bagi wanita selama kehamilan ketiga yang membuat wanita lebih mudah terkena infeksi HPV dan pertumbuhan kanker. Berbagai pendapat mengatakan bahwa wanita hamil memiliki imunitas yang lebih rendah sehingga memudahkan masuknya HPV dalam tubuh. ${ }^{(10)}$

Berdasarkan hasil penelitin ini sebaiknya diberikan pendidikan kesehatan kepada keluarga tentang pentingya membatasi jumlah anak. Jumlah anak banyak yang dimiliki oleh responden juga dipengaruhi oleh faktor lingkungan sekitar dan sebagian besar responden yang berstatus sebagai ibu rumah tangga. Program keluarga berencana sebaiknya lebih ditingkatkan untuk meurunkan jumlah kelahiran.

Berdasarkan penggunaan kontrasepsi hormonal ibu yang menggunakan kontrasepsi hormonal 4-5 tahun lebih banyak ditemukan pada ibu iva tes positif $(81.5 \%)$ dibandingkan dengan ibu dengan iva tes negatif (18.5\%). Uji statistik Chi-Square menunjukkan terdapat hubungan yang bermakna antara hasil pemeriksaan IVA dengan penggunaan kontrasepsi hormonal wanita.

Hasil penelitia ini sama dengan penelitian yang dilakukan oleh Widiyanti, 2020 yang berjudul faktorfaktor yang mempengaruhi hasil pemeriksaan iva test di poliklinik Yayasan kanker Indonesia kota Cimahi yang menyatakan terdapat hubungan yang bermakna antara riwayat penggunaan kontrasepsi hormonal dengan hasil iva test. Hasil penelitian Wahyuningsih 2014 yang berjudul faktor risiko terjadinya lesi prakanker serviks melalui deteksi dini dengan metode IVA menyatakan terdapat hubungan yang bermakna antara riwayat penggunaan kontrasepsi hormonal dengan hasil iva test.

Wanita yang menggunakan kontrasepsi hormonal selama 4-5 tahun memiliki risiko kanker servik lebih tinggi dibandingkan yang tidak menggunakan kontraspesi hormonal. Haln ini dapat terjadi karena vagina menjadi kering dan menyebabkan rasa sakit (dispareuni) saat melakukan hubungan seksual, akibat kontrasepsi hormonal. Jika kondisi ini berlangsung lama maka akan menimbulkan penurunan gairah serta disfungsi seksual pada wanita, serta keadaan ini dapat memicu terpaparnya vagina oleh virus HPV akibat adanya iritasi. ${ }^{(10)}$

Berdasarkan hasil penelitian tentang penggunaan kontrasepsi hormonal dengan hasil pemeriksaan iva tes tersebut dapat disimpulkan bahwa sebagian besar responden mengatakan mereka menggunakan kontrasepsi hormonal >4-5 tahun dikarenakan responden ingin menjarakkan jumlah kelahiran sehingga menggunakan kontrasepsi hormonal yang memiliki jangka waktu yang panjang dan penggunaan yang mudah ddan efisien seperti penggunaan suntik hormonal, implant dan IUD hormonal.

\section{KESIMPULAN}

Berdasarkan hasil penelitian faktor risiko hasil pemeriksaan iva test didapatkan bahwa ibu yang menikah diumur $<20$ tahun, ibu yang melahirkan anak lebih dari 3 kali dan ibu yang menggunakan kontrasepsi hormonal 4 sampai 5 tahun memiliki faktor risiko terhadap kejadian IVA test positif.

\section{DAFTAR PUSTAKA}

1. Ika Putri Damayanti. 2013. Faktor-Faktor yang Berhubungan Dengan Kejadian Kanker Serviks di RSUD Arifin Achmad Pekanbaru Tahun 20082010. Jurnal Kesehatan Komunitas Vol 2 No 2.

2. World Health Organization. 2018. Cancer Country Profiles:Indonesia. Cancer Country Profiles

3. Rasjidi Imam. 2009. Epidemiologi Kanker Serviks. Indonesian Journal Of Cancer Vol III. No 3.

4. Kementerian Kesehatan Republik Indonesia. Profil Kesehatan Indonesia 2010. Jakarta: Kemenkes RI; 2015

5. Widiyanti Ranti, Septriliyana Noucie. 2020. Faktor-Faktor yang Mempengaruhi Hasil Pemeriksaan Iva Test di Poliklinik Yayasan Kanker Indonesia Kota Cimahi. Jurnal Ummu Serambi Sehat. Vol 13 No 2.

6. Juanda Desby, Kesuma Hardians. 2015. Pemriksaan Metode IVA (Inspeksi Visual Asam Asetat) untuk Pencegahan Kanker Serviks. Jurnal Kedokteran dan Kesehatan. Vol 2 No 2.

7. Setyarini Eka. 2009. Faktor-Faktor yang berhubungan dengan kejadian kanker leher rahim di RSUD Dr. Maoewardi Surakarta. Universitas Muhammdiyah Surakarta.

8. Wahyuningsih Tri, Mulyani Erry Yudhya. 2014. Faktor Risiko Terjadinya Lesi Prakanker Serviks Melalui Deteksi Dini Dengan Metode IVA. Forum Ilmiah. Vol 11 No 2.

9. Ningsih Dwi Putri Sulistiya, Pramono Dibyo, Murdiati Detty. 2017. BKM Journal of Community Medicine and Public Health. Vol 33 Nomor 3.

10. Paremajangga Rambu Aji, Ndoen Honey I, Riwu Yuliana R. 2020. Faktor Risiko yang Berhubungan Dengan Kejadian Lesi Prakanker Serviks IVA 
positif diPuskesmas Bakunase Kota Kupang Tahun 2019. Media Kesehatan Masyarakat. Vol 2 No 1 